\title{
Further evidence that imbalance of WT1 isoforms may be involved in Denys - Drash syndrome
}

\author{
Anja Könlg, Sybille Jakublczka', Peter Wleacker', Hans W.Schlösser ${ }^{2}$ and Mantred Gessler * \\ Instutut für Humangenetik, Philippe-Unverstat. Bahnhotstraße 7A, 0-35037 Marburg, IInstutut für Humangenotik, Medizinische Hochschule Hannover, D-3000 Hannover 61 \\ and 2Frauendfink der Medizanischen Hochschule Hannover, Oststadtkrankenhaus, D-3000 Hannover, Germany
}

Received July 7, 1993; Revised and Accepted August 13, 1993

Denys - Drash syndrome (DDS) is a rare developmental disorder of the genito-urinary system characterized by severe nephropathy, genital abnormalities and a predisposition to Wilms' tumor (Denys, 1967, Drash, 1970). All components of the syndrome appear to be caused by dominant mutations of the WTI Wilms' tumor gene (Pelletier et al., 1991). WTl has first been identified as a tumor suppressor gene that is deleted or inactivated in a certain fraction of Wilms' tumors (Call et al., 1990; Gessler $e t$ al., 1990). The gene encodes a DNA-binding zinc finger protein that can regulate transcription of other genes (Rauscher et al., 1990).

The majority of WTl mutations detected in DDS patients are highly specific point mutations that alter DNA contact sites within the zinc finger domain of the $W T l$ protein (Pelletier et al., 1991). More recently, some cases were described where the WTI mutations would result in a truncated $W T l$ protein that is missing all or part of the zinc finger domain (Baird et al., 1992; Little et al., 1993; Ogawa et al., 1993). These observations favor the interpretation of DDS mutations as dominant negative mutations where a shortened $W T 1$ polypeptide competes with wild-type protein produced from the remaining normal WTI allele for effector sites.

A single case, patient C.S., described by Bruening $e t$ al. (1992), however, suggested that even alterations in the balance between alternatively spliced forms of $W T I$ may be sufficient to generate DDS. There are two sites of alternative splicing in the WT1 gene (Haber et al., 1991; Gessler et al., 1992). The first, leading to the presence or absence of exon 5 has not been associated with a functional correlate. The second site is found at the end of exon 9 where two splice donor sites, located within 9 basepairs, can be used, resulting in the insertion of 3 amino acids ( + KTS) between zinc fingers 3 and 4 with concomitant changes in the DNA binding characteristics of the resulting zinc fingers (Rauscher et al., 1990; Bickmore et al., 1992). The relative ratio of the different $W T I$ isoforms appears constant in all cases examined with the longer prochucts being more abundant.

Here, we describe a new case of DDS, patient J.A., where a mutation in one of the splice donor sites of exon 9, identical to the one described in patient C.S., has been found supporting the concept that the balance of WTI isoforms is critical for normal a)

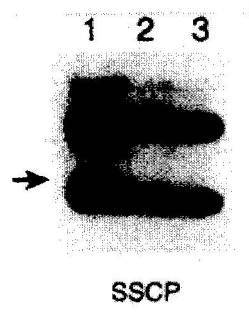

c)

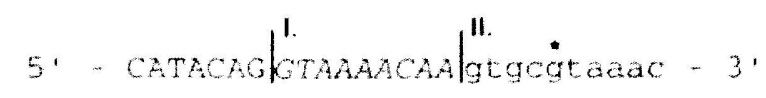

b)

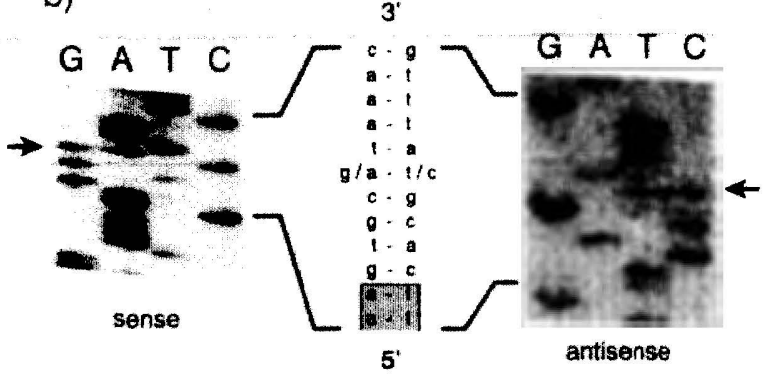

$$
\text { ' }
$$

Figure 1. a) SSCP analysis of exon 9 in patient J.A. (lane 1) and two control DNAs (2,3). PCR amplification from white blood cell DNA and denaturation of radiolabeled products were done as described (Poulat et al., 1993). Samples were separated on a $6 \%$ potyacrylamide gel at $30 \mathrm{~W}$ and $4^{\circ} \mathrm{C}$, followed by drying and autoradiography. The arrow marks the location of the new band detected in patient J.A. b) For direct sequence analysis exon 9 was amplified from genomic DNA and purified using Magic DNA Cleanup (Promega). The 248 bp fragment was sequenced from both ends by Taq cycle sequencing using ${ }^{32}$ P-labelled primers (fmol kit, Promega). The double band G/A (sense strand) and T/C (antisense strand) was not seen in sequences from control DNAs. c) sequence of the exon/intron junction. Both aiternative splice sites (I and II) are shown with the mutation site marked by an asterisk.

- To whom comespondence strould be addressed 
development. Patient J.A. was suspected to have DDS based on clinical criteria. J.A. is a 13 year old female child with inconspicuous family history. Renal insufficiency was observed from the age of 2 years on. Chronic glomerulonephritis made dialysis necessary from the age of 8 years on and led to renal transplantation at 11.5 years. The girl was growth retarded and showed primary amenorrhea. External genitalia were normal female with endocrinological investigations revealing a hypergonadotrophic hypogonadism. The cytogenetic examination of peripheral blood lymphocytes showed a normal male karyotype. The combination of gonadal dysgenesis and chronic renal failure resulting from glomerular disease suggested the diagnosis of DDS.

Because of the increased risk of malignancy gonads were removed. At laparotomy, uterus, Fallopian tubes and streak gonads were observed. Histologic examination showed normal Fallopian tubes, a ductus epididymis and dysgenetic gonadal tissue without typical testicular structures. The analysis of fibroblast cultures from the streak gonads also revealed a normal male karyotype. The clinical picture with Müllerian structures present suggests that the AMH-producing fetal cells must have degenerated early. On the other hand, testosteron-producing Leydig cells must also have been active for some time, as a ductus epididymis was present.

During initial molecular studies a deletion of the $\mathrm{Y}$ chromosome was not detected by PCR-studies employing primer pairs of the following loci: PABY, SRY, ZFY, DYS19, DYS14, alphasatellite, DXYS19, and DYZL (data not shown).

To search for possible alterations of WTI in this patient the coding region of the gene was assayed by SSCP analysis (Orita et al., 1989). Only in exon 9 a slight alteration of the bands could be detected. The incomplete separation of the variant band from the normal band precluded direct analysis of the altered fragment. Exon 9 was therefore amplified from genomic DNA and sequenced directly from both ends. A single alteration could be detected in repeated sequencing reactions resulting in a $G \rightarrow A$ transversion in intron 9 , five basepairs downstream the splice donor site (Figure 1). This is the same mutation as described in DDS patient C.S. by Bruening et al. (1992). These authors have shown by transfection of minigene constructs containing $W T 1$ exons 9 and 10 that this alteration abolishes the use of the second alternative splice donor site at exon 9. Thus, the longer $+\mathrm{KTS}$ isoform of the $W T 1$ protein can only be produced from the remaining normal allele, leading to an altered balance between these protein isoforms. The independent finding of the same kind of splicing mutant in a second patient with DDS provides additional evidence that the precise ratio of different WTI isoforms may be critical during certain steps of kidney and gonadal development.

\section{ACKNOWLEDGEMENT}

This work was supported by a grant from the Deursche Forschungsgemeinschaft (Ges39/3-3).

\section{REFERENCES}

1. Baird,P.N., Santos,A., Groves, N., Jadrasic, L. and Cowell,J.X. (1992) Hum. MoL. Gena. 1, $301-305$.

2. Bruening,W., Bardeesy,N., Silverman,B.L., Cohn,R.A., Machin,G.A., Aronson,A.J., Housman,D. and Pelletier.J. (1992) Nature Genetics 1, $144-148$.
3. Call,K.M., Glaser,T., Ito,C.Y., Buckler,A.J., Pelletier,J., Haber,D.A., Rose,E.A., Kral,A., Yeger,H., Lewis, W.H., et al (1990) Cell 60, 509-520.

4. Denys, P., Malvaux,P., van den Berghe,H., Tanghe,W. and Proesmans,W. (1967) Arch. Fran. Ped. 24, 729-739.

5. Drash,A., Sherman,F., Harmam,W.H. and Blizzard,R.M. (1970) J. Pectianr. 76, $585-593$.

6. Gessler,M., Konig,A. and Bruns,G.A. (1992) Genomics 12, 807-813.

7. Gessler,M., Poustka,A., Cavenee,W., Neve,R.L., Orkin,S.H. and Bruns,G.A. (1990) Nature 343, 774-778.

8. Haber,D.A., Sohn,R.L., BuckJer,A.J., Pelletier,J., Call,K.M. and Housman,D.E. (1991) Proc. Natl. Acad. Sci. U S A 88, 9618-9622.

9. Little,M.H., Williamson,K.A., Mannens,M., Kelsey,A., Gosden,C., Hastie,N.D. and van Heyningen, V. (1993) Hum. Mal. Genet. 2, 259-264.

10. Ogawa,O., Eccles,M.R., Yun,K., Mueller,R.F., Holdaway,M.D.D. and Reeve,A.E. (1993) Hum. Mol. Genet. 2, 203-204.

11. Orita,M., Suzuk,,Y., Sekjya,T. and Hayashi,K. (1989) Genomics 5, 874-879.

12. Pelletier,J., Bruening,W., Kashtan,C.E., Mauer,S.M., Manivel,J.C., Striegel,J.E., Houghton,D.C., Junien,C., Habib,R., Fouser,L. et al. (1991) Cell 67, 437-447.

13. Poulat,F., Morin,D., Kőng,,A., Brun,P., Giltay,J., Sultan,C., Dumas,R., Gessler, M. and Berta,P. (1993) Hum. Genet. 91, 285-286.

14. Rauscher,F.J., Morris,J.F., Tournay,O.E., Cook,D.M. and Curran,T. (1990) Science 250, 1259-1262. 